\title{
Analysis of hemocyte parameters in Pacific oysters, Crassostrea gigas, reared in the field - Comparison of hatchery diploids and diploids from natural beds
}

\author{
Gagnaire Beatrice $^{1}$, Soletchnik Patrick ${ }^{2}$, Faury Nicole ${ }^{2}$, Kerdudou Nolwenn ${ }^{1}$, Le Moine \\ Olivier $^{2}$ and Renault Tristan ${ }^{1^{*}}$
}

\author{
${ }^{1}$ IFREMER, Laboratoire de Génétique et Pathologie (LGP), 17390 La Tremblade \\ ${ }^{2}$ IFREMER, Laboratoire Environnement et Ressources des Pertuis Charentais (LERPC), 17390 La \\ Tremblade
}

*: Corresponding author : Corresponding author: Tristan Renault, IFREMER, LGP, 17390 La Tremblade, Tel: 335467626 49, Fax: 335467626 11, E-mail: trenault@ifremer.fr

\begin{abstract}
:
nternal defence mechanisms of bivalves include the hemocytes which assume several functions. Relationships exist between environmental factors, physiological state of oysters, defence system and pathogens. Hatchery oysters are more and more produced and reared in the field. The characteristics and particularly the defence system of these animals are poorly documented. In this context, two field trials were carried out from May to September 2002 and from April to July 2003 in order to monitor hemocyte parameters of diploid oysters from natural beds and hatchery-produced diploid oysters using flow cytometry. Several hemocyte parameters (cell mortality, granulocyte percentage, phagocytosis, esterase and peroxidase activities) were monitored. For both oyster groups, trend of hemocyte parameters in 2002 and 2003 are reported. For several parameters, values tended to increase over the sampling period in both experiments. For both experiments, phagocytosis was higher for diploids from natural beds compared to hatchery diploids. This is the first study in which trend of hemocyte parameters from the Pacific oyster, Crassostrea gigas, was monitored with short sampling intervals and to compare hatchery diploids and diploids from natural beds.
\end{abstract}

Keywords: Pacific oyster, Crassostrea gigas; hemocytes; phagocytosis; esterase activity; peroxidase activity; flow cytometry; diploids; natural beds; hatchery. 


\section{Introduction}

Internal defence mechanisms of bivalves involve circulating cells, the hemocytes. In Crassostrea gigas, two types of hemocytes can be differentiated on the basis of morphological features: hyalinocytes and granulocytes (Cheng, 1981). Hemocytes are involved in the recognition of invading pathogens and in their elimination by phagocytosis and encapsulation (Cheng, 1981; Fisher, 1986). Hydrolytic enzymes including esterases and reactive oxygen species (ROS) produced by phagocytic cells play a key role in pathogen killing (Carballal et al., 1997; Hine, 1999). They have been used as immune capacity indicators in different bivalve species (Auffret et al., 2002; Lambert et al., 2003).

Recent studies show that oyster defences against pathogens including bacteria are influenced both by environmental and physiological parameters (Fisher, 1988; Chu and Hale, 1994; Volety et al., 1999). Environmental conditions or the presence of oyster parasites such as the protozoan Perkinsus marinus may suppress the bactericidal activity of hemocytes, and lead to the accumulation of bacteria in bivalve tissues (Tamplin and Capers, 1992; Tall et al., 1999). Furthermore, stress and disease outbreaks sometimes appear to be linked in molluscs (Friedman et al., 1999; Lacoste et al., 2001). As a consequence, possible relationships between environmental factors, the physiological state of oysters, their immune system and pathogens needs further investigations.

Triploid and diploid oysters are nowadays more and more produced in hatcheries (Nell, 2002) and represents an increasing part of shellfish culture in the field (Soletchnik et al., 2002). However, this way of production leads to animal selection. The characteristics and particularly the defence system of these animals may be different from the defence system of diploids from natural beds. It appears important to know if these animals are able to respond to environmental pressures as well as natural bed oysters.

In 2002 and 2003, two field trials were carried out in Ronce les Bains (Charente Maritime, Altantic coast, France) in order to monitor hemocyte parameters of two groups of Pacific oysters during the summer period. Diploids from natural beds and hatchery bred diploids were deployed in the field. Hemocyte parameters including granulocyte percentage, phagocytosis, percentages of cells possessing hydrolytic enzymes (esterases, peroxidases) were investigated using flow cytometry. Flow cytometry is well suited to morphological and functional characterisation of oyster hemocytes (Fournier et al., 2001; Renault et al., 2001; Sauvé et al., 2002). In 2002, the sampling period lasted from May to September, and in 2003, from April to July. These periods were chosen because in Marennes-Oleron Basin (Charente-Maritime, France), a high increase in water temperature is reported every year from March to September (Soletchnik et al., 1998). Moreover, in Marennes-Oleron Bay, this period is the one when mortality outbreaks occur (Soletchnik et al., 1999). Intervals between sampling dates were short for both years (one or two weeks) in order to monitor the trend of hemocyte parameters of both oyster groups throughout the sampling period. 


\section{Material and Methods}

\subsection{Experimental oysters}

Two oyster groups were studied: diploid oysters from natural beds (D) and hatchery diploid oysters (Dh), during two field trials carried out in 2002 and 2003. For each experiment, D were 1.5 year-old wild oysters from Marennes-Oleron Bay (French Atlantic coast) and Dh were 1.5 year-old hatchery reared oysters from the IFREMER experimental hatchery located in La Tremblade (Charente Maritime, France). D oysters were grown in the south of the Marennes-Oleron Bay in bags placed on tables. Dh oysters were placed in these conditions two months before the beginning of the experiment each year. Sampling dates were: May 14 and 28; June 6, 12, 20 and 26; July 3, 25; August 8, 21 and September 11 in 2002. Sampling dates were: April 22; May 14 and 26; June 2, 10, 16, 19, 23 and 26; July 16 in 2003.

\subsection{Circulating hemocyte collection}

After removing the shell by severing the adductor muscle, hemolymph was withdrawn directly from the pericardial cavity by puncture with a $1 \mathrm{~mL}$ syringe equipped with a needle $(0.9525 \mathrm{~mm})$. For each oyster, $0.5 \mathrm{~mL}$ of hemolymph was withdrawn without any buffer. Hemolymph samples were conserved on ice during collection to limit hemocyte aggregation (Xue et al., 2001). For each group (D and Dh), thirty oysters were sampled at each date. The samples were combined into three pools of 10 oysters each to reduce individual variation and to provide sufficient hemocytes to fulfil assay requirements.

\subsection{Cell analysis by flow cytometry}

Hemocytes were analysed with an EPICS XL 4 flow cytometer (Beckman Coulter) using previously described protocols (Gagnaire et al., 2004) immediately after hemocyte collection and staining for all selected parameters. For each hemocyte pool, 3000 events were counted. Results were depicted as cell cytograms indicating the relative size (FSC value), the granularity (SSC value) and the fluorescence channel(s) corresponded to the marker used. Percentages of esterase and peroxidase positive cells and phagocytosis were measured based on green fluorescence (FL1) and cell mortality based on red fluorescence (FL3).

Esterase (Est) and peroxidase (Per) activities were evaluated using commercial kits (Cell Probe ${ }^{\mathrm{TM}}$ Reagents, Beckman Coulter). Percentages of cells presenting enzymatic activities were defined on the basis of fluorescent cells among all cells. Each analysis required $200 \mu \mathrm{L}$ of hemolymph and $20 \mu \mathrm{L}$ of the corresponding kit reagent (FDA (Fluorescein Diacetate)•Esterase and DFCH (Dichlorofluorescein Diacetate)-PMA (Phorbol-12-Myristate-13-Acetate)•Oxidative Burst). Hemocytes were then incubated in the dark at ambient temperature for 15 minutes for esterase and peroxidase detection. Hemocyte mortality $(\mathrm{Hm})$ was quantified using $200 \mu \mathrm{L}$ of hemolymph. Hemocytes were incubated in the dark for 30 minutes at $4{ }^{\circ} \mathrm{C}$ with $10 \mu \mathrm{L}$ of propidium iodide (PI, $1.0 \mathrm{mg}^{\mathrm{mL}} \mathrm{m}^{-1}$, Interchim) for a final concentration of $50 \mu \mathrm{g} \cdot \mathrm{mL}^{-1}$. Morphological characteristics of hemocytes were also recorded: gates were set on the SSC/FSC plot on the most granular and largest cells in order to determine a granulocyte population (Gra). Phagocytosis (Pha) was measured in vitro as the proportion of cells that had ingested three or more fluorescent beads (Xue et al., 2001; Gagnaire et al., 2004). Two hundred $\mu \mathrm{L}$ of hemolymph were incubated for one hour in the dark at ambient temperature with $10 \mu \mathrm{L}$ of a 1/10 dilution of Fluorospheres ${ }^{\circledR}$ carboxylate-modified microspheres (diameter $1 \mu \mathrm{m}$, Interchim). The final concentration of beads was $10^{8}$ beads. $\mathrm{mL}^{-1}$ and the final ration beads/hemocytes was 100/1.

\subsection{Statistical analysis}

Two-ways ANOVAs and Student tests were carried out using Statgraphics ${ }^{\circledR}$ Plus version 5.1 software. Hemocyte parameters were converted into $r$ angular arc sinus $\sqrt{ }$ (\% of mortality) before analysis in order to obtain normal values. Figures were drawn using non-transformed percentage values. In case of a rejection of Ho, an a posteriori LSD (Least Significant Difference) test was applied. 


\section{Results}

\subsection{2}

Cell mortality was low except for Dh the 07/25 where a brief increase was observed (Figure 2a). Another peak, but less important, was observed for $D$ at 08/08 (Figure 2a). Peroxidase values increased over the sampling period for both animal groups from $2 \%$ (end of May) to $25-45 \%$ in September, with a decrease at the end of June and an increase in August (Figure 2b). During this increase, values were higher for D oysters compared to Dh oysters (Figure 2b). Esterase positive cells increased for both oyster groups from $2 \%$ in May to 20-30 \% in June-July and 60-80 \% in August (Figure 2c). Values for D were higher than for Dh in August. After the 08/08, values decreased (Figure 2c). Phagocytosis decreased for both oyster groups at the beginning of June (2-7\%), then increased during summer (Figure 2d). Highest values were reached in September. During this increase, values were higher for D oysters compared to Dh oysters (example: on 09/11, 38.3 \% and $53.0 \%$ for Dh and D, respectively) (Figure 2d). Granulocyte values ranged between $4 \%$ and $20 \%$ during the sampling period for both oyster groups, except for 07/25 where a high value $(63.1 \%)$ was recorded for D (Figure 2e).

Water temperature increased during the experiment and reached a maximum of $21.4^{\circ} \mathrm{C}$ in mid-August (Figure 1). Water temperature appeared positively correlated to granulocyte percentage for $\mathrm{Dh}$ $(p<0.05)$.

\subsection{3}

Cell mortality presented low values and increased over the sampling period for both oyster groups (Figure 3a). Peroxidase values presented similar variations for both diploid groups and were slightly higher in April May and July for D oysters (Figure 3b). Esterase positive cells decreased for both oyster groups from April to the end of June, except a high value for both diploids at the end of June (Figure 3c). From April to June, values were higher for D oysters (Figure 3c). Phagocytosis decreased for both oyster groups from April to May, then increased in June and decreased again (Figure 3d). In April and June, values were higher for D oysters (Figure 3d). Granulocytes values ranged between 4 $\%$ and $10 \%$ throughout the sampling period for both oyster groups (Figure 3e).

Water temperature increased during the experiment and reached a maximum of $23.2^{\circ} \mathrm{C}$ in mid-July (Figure 1). Water temperature appeared positively correlated to cell mortality for $D$ and $\mathrm{Dh}(\mathrm{p}<0.01)$ and negatively correlated to percentage of esterase positive cells for $\mathrm{Dh}(\mathrm{p}<0.05)$.

When pooling the data of the whole sampling period, ANOVA showed that phagocytosis values were higher in D oysters compared to Dh oysters, in $2002(p<0.05)$ and in $2003(p<0.05)$. The other hemocyte parameters presented no significant difference. 


\section{Discussion}

The hemocyte parameters selected were phagocytosis, presence of esterases and peroxidases, hemocyte mortality, and percentage of granulocytes. These parameters are frequently analysed to study the immune system in bivalves. Phagocytosis can be measured by chemiluminescence (Anderson et al., 1994). Esterase and peroxidase activities have been measured by electron microscopy (Pipe, 1992). Moreover, some of these activities, including phagocytosis, cell mortality, and esterase and peroxidase activities have already been analysed using flow cytometry in bivalves and vertebrates (Malin-Berdel and Valet, 1980; Alvarez et al., 1989; Sauvé et al., 2002).

Although hemocyte parameters including phagocytosis or free radical production are frequently used to define the immune status in bivalves (Cheng and Sullivan, 1984; Alvarez et al., 1989; Anderson et al., 1994), studies reporting temporal variations of such parameters are less frequent. Moreover, when such studies have been carried out, the frequency of sample collection was often low (Pipe et al., 1995; Auffret and Oubella, 1997; Fisher et al., 2000; Oliver et al., 2001). One of the purpose of the present study was to use flow cytometry to analyse variations of hemocyte parameters during a sevenmonth period during which samples were collected approximately every 7 to 14 days.

Values increased during the course of the experiments from spring to summer in both oyster groups, $D$ and Dh. No study has reported temporal trend of hemocyte parameters in C. gigas. However, some studies report differences in hemocyte characteristics in bivalves depending on the season. Pipe et al. (1995) described seasonal changes in Mytilus edulis hemocyte parameters and demonstrated a minimal phagocytosis activity in April and a minimal peroxidase activity in June. Antioxidant enzymes, lysozyme and number of circulating hemocytes fluctuated depending on the season (Sole et al., 1995; Fisher et al., 2000; Oliver et al., 2001). Some correlations were demonstrated between temperature and hemocyte parameters mostly in 2003. Percentage of esterase positive cells was negatively correlated to water temperature. An increase in water temperature induces an increase of physiological activities (Cheney et al., 2000; Peck et al., 2002) and may also enhance hemocyte activities. However, a study reported also a negative correlation between acetylcholinesterase and water temperature (Robillard et al., 2003). Cell mortality and granulocyte percentage were positively correlated to water temperature and increased at the same dates. A study on separation of hyalinocytes and granulocytes in C. gigas observed that when manipulated, granulocytes were sensitive (degranulation observed) (Bachere et al., 1988). Granulocytes may be more sensitive also to environmental factors. An increase of hemocyte mortality at high temperatures was reported before (Gagnaire et al., 2006). An experiment conducted on Mytilus edulis showed that phagocytosis and the number of circulating cells increased after a temperature increase (Parry and Pipe, 2004). However, no such relationships was found in our study.

Phagocytosis was lower on Dh for both years. Phagocytosis is one of the most important defence activities in bivalve hemocytes (Cheng, 1983; Alvarez et al., 1989; Goedken and De Guise, 2004). These results tend to show that hatchery-produced oysters may possess a defence system different from oysters from natural beds. As this study is the first one to compare oysters from hatchery and from natural beds, the biological basis of such differences are unknown. We can hypothesize the role of the reduced heterozygosity. This could lead to a deficiency in variability which could be important for the defence mechanisms. Hatchery-produced oysters may be less immunocompetent than oysters from natural beds. However, phagocytosis differences observed in our study between $D$ and Dh were small.

The difference between the defence mechanisms of hatchery and non-hatchery-produced oysters showed in this study needs to be clarified. In fact, in our study, we measured phagocytosis activity by the internalisation of inert beads. This measure may not directly reflect an immune capacity, although most studies on bivalves use it as a biomarker of defence system (Goedken and De Guise, 2004). The correlation between a capacity of bead phagocytosis and susceptibility to pathogens should be established. By using pathogen challenges, it would be possible to show if there are differences in susceptibility to infectious diseases between hatchery-bred oysters and natural oysters. 


\section{Conclusion}

This study showed that there could be some differences in the hemocyte parameters of oysters from hatchery and from natural beds. Further work is needed in order to understand these differences and their significance.

\section{Acknowledgements}

The authors would like to thank to Dr J.F. Samain (IFREMER, Brest, France) for managing the MOREST project group of research. Dr. P. Boudry and Dr. L. Degremont of the Laboratory of Genetic and Pathology of La Tremblade and the entire hatchery team are acknowledged for their contribution to oysters production. Dr. Philippe Goulletquer is acknowledged for his permission to perform these experiments in the laboratory. The authors also want to thank the Pr Susan Ford for her reading and her helpful corrections of these papers. The study was partly financially supported by the PoitouCharentes Region. 


\section{References}

Alvarez, M.R., Friedl, F.E., Johnson, J.S., Hinsch, G.W., 1989. Factors affecting in vitro phagocytosis by oyster hemocytes. Journal of Invertebrate Pathology 54, 233-241.

Anderson, R.S., Mora, L.M., Thomson, S.A., 1994. Modulation of oyster (Crassostrea virginica) hemocyte immune function by copper, as measured by luminol-enhanced chemiluminescence. Comparative Biochemistry and Physiology Part C: Pharmacology, Toxicology and Endocrinology 108, 215-220.

Auffret, M., Oubella, R., 1997. Hemocyte aggregation in the oyster Crassostrea gigas: In vitro measurement and experimental modulation by xenobiotics. Comparative Biochemistry and Physiology Part A: Molecular \& Integrative Physiology 118, 705-712.

Auffret, M., Mujdzic, N., Corporeau, C., Moraga, D., 2002. Xenobiotic-induced immunomodulation in the European flat oyster, Ostrea edulis. Marine Environmental Research 54, 585-589.

Bachere, E., Chagot, D. and Grizel, H., 1988. Separation of hemocytes by density gradient centrifugation and counterflow centrifugal elutriation. Developmental \& Comparative Immunology 12, 549-559.

Carballal, M.J., Lopez, C., Azevedo, C., Villalba, A., 1997. Enzymes involved in defense functions of hemocytes of Mussel Mytilus galloprovincialis. Journal of Invertebrate Pathology 70, 96-105.

Cheney, D.P., MacDonald, B.F., Elston, R.A., 2000. Summer mortality of Pacific oysters, Crassostrea gigas (Thunberg): Initial findings on multiple environmental stressors in Puget Sound, Washington, 1998. J. Shellfish Res. 19, 353-359.

Cheng, T.C., 1981. Bivalves. In: Ratcliffe, N.A., Rowley, A.F. (Eds.), Invertebrate Blood Cells I. Academic Press, London, pp. 233-299.

Cheng, T.C., 1983. The role of lysosomes in molluscan inflammation. American Zoology 23, 129-144.

Cheng, T.C., Sullivan, J.T., 1984. Effects of heavy metals on phagocytosis by molluscan hemocytes. Marine Environmental Research 14, 305-315.

Chu, F.-L.E., Hale, R.C., 1994. Relationship between pollution and susceptibility to infectious disease in the eastern oyster, Crassostrea virginica. Marine Environmental Research 38, 243-256.

Fisher, S.W., 1986. Structure and functions of oyster hemocytes. In: Brehélin, M. (Ed.), Immunity in Invertebrates. Springer-Vrelag, Berlin Heidelberg, pp. 25-35.

Fisher, S.W., 1988. Environmental influence on host response: environmental influence on bivalve hemocyte function. American Fisheries Society Special Publication 18, 225-237.

Fisher, W.S., Oliver, L.M., Winstead, J.T., Long, E.R., 2000. A survey of oysters Crassostrea virginica from Tampa Bay, Florida: associations of internal defense measurements with contaminant burdens. Aquatic Toxicology 51, 115-138.

Friedman, C.S., Cherr, G.N., Clegg, J.S., Hamdoun, A.H., Jacobsen, J.L., Jackson, S.A., Uhlinger, K.R., 1999. Investigation of the stress response, summer mortality and disease resistance of oysters, Crassostrea spp. National Shellfisheries Association.

Gagnaire, B., Thomas-Guyon, H., Renault, T., 2004. In vitro effects of cadmium and mercury on Pacific oyster, Crassostrea gigas (Thunberg), haemocytes. Fish \& Shellfish Immunology 16, 501-512.

Gagnaire, B., Frouin, H., Moreau, K., Thomas-Guyon, H., Renault, T., 2006. Effects of temperature and salinity on haemocyte activities of the Pacific oyster, Crassostrea gigas (Thunberg). Fish \& Shellfish Immunology 20, 536-547.

Goedken, M., De Guise, S., 2004. Flow cytometry as a tool to quantify oyster defence mechanisms. Fish \& Shellfish Immunology 16, 539-552.

Hine, P.M., 1999. The inter-relationships of bivalve haemocytes. Fish \& Shellfish Immunology 9, 367385.

Lacoste, A., Jalabert, F., Malham, S., Cueff, A., Gelebart, F., Cordevant, C., Lange, M., Poulet, S.A., 2001. A Vibrio splendidus strain is associated with summer mortality of juvenile oysters Crassostrea gigas in the Bay of Morlaix (North Brittany, France). Diseases of Aquatic Organisms 46, 139-145.

Lambert, C., Soudant, P., Choquet, G., Paillard, C., 2003. Measurement of Crassostrea gigas hemocyte oxidative metabolism by flow cytometry and the inhibiting capacity of pathogenic vibrios. Fish \& Shellfish Immunology 15, 225-240.

Malin-Berdel, J., Valet, G., 1980. Flow cytometric determination of esterase and phosphatase activities and kinetics in hematopoietic cells with fluorogenic substrates. Cytometry 1, 222-228.

Nell, J.A., 2002. Farming triploid oysters. Aquaculture 210, 69-88. 
Oliver, L.M., Fisher, W.S., Winstead, J.T., Hemmer, B.L., Long, E.R., 2001. Relationships between tissue contaminants and defense-related characteristics of oysters (Crassostrea virginica) from five Florida bays. Aquatic Toxicology 55, 203-222.

Parry, H.E., Pipe, R.K., 2004. Interactive effects of temperature and copper on immunocompetence and disease susceptibility in mussels (Mytilus edulis). Aquatic Toxicology 69, 311-325.

Peck, L.S., Portner, H.O., Hardewig, I., 2002. Metabolic demand, oxygen supply, and critical temperatures in the Antarctic bivalve Laternula elliptica. Physiological and Biochemical Zoology 75, 123-133.

Pipe, R.K., 1992. Generation of reactive oxygen metabolites by the haemocytes of the mussel Mytilus edulis. Dev. Comp. Immunol. 16, 111-122.

Pipe, R.K., Coles, J.A., Thomas, M.E., Fossato, V.U., Pulsford, A.L., 1995. Evidence for environmentally derived immunomodulation in mussels from the Venice Lagoon. Aquatic Toxicology 32, 59-73.

Robillard, S., Beauchamp, G., Laulier, M., 2003. The role of abiotic factors and pesticide levels on enzymatic activity in the freshwater mussel Anodonta cygnea at three different exposure sites. Comparative Biochemistry and Physiology Part C: Toxicology \& Pharmacology 135, 49-59.

Sauvé, S., Brousseau, P., Pellerin, J., Morin, Y., Senecal, L., Goudreau, P., Fournier, M., 2002. Phagocytic activity of marine and freshwater bivalves: in vitro exposure of hemocytes to metals (Ag, Cd, Hg and Zn). Aquatic Toxicology 58, 189-200.

Sole, M., Porte, C., Albaiges, J., 1995. The use of biomarkers for assessing the effects of organic pollution in mussels. Science of the Total Environment 159, 147-153.

Soletchnik, P., Faury, N., Razet, D., Goulletquer, P., 1998. Hydrobiology of the Marennes-Oleron Bay. Seasonal indices and analysis of trends from 1978 to 1995. Hydrobiologia 386, 131-146.

Soletchnik, P., Le Moine, O., Faury, N., Razet, D., Geairon, P., Goulletquer, P., 1999. Summer mortality of the oyster Crassostrea gigas in the Bay Marennes-Oleron: spatial variability of environnement and biology using a geographical information system (GIS). Aquatic Living Resources 12, 131-143.

Soletchnik, P., Huvet, A., Le Moine, O., Razet, D., Geairon, P., Faury, N., Goulletquer, P., Boudry, P., 2002. A comparative field study of growth, survival and reproduction of Crassostrea gigas, C. angulata and their hybrids. Aquatic Living Resources 15, 243-250.

Tall, B.D., La Peyre, J.F., Bier, J.W., Miliotis, M.D., Hanes, D.E., Kothary, M.H., Shah, D.B., Faisal, M., 1999. Perkinsus marinus extracellular protease modulates survival of Vibrio vulnificus in Eastern oyster (Crassostrea virginica) hemocytes. Appl. Environ. Microbiol. 65, 4261-4263.

Tamplin, M.L., Capers, G.M., 1992. Persistence of Vibrio vulnificus in tissues of Gulf Coast oysters, Crassostrea virginica, exposed to seawater disinfected with UV light. Appl. Environ. Microbiol. 58, 1506-1510.

Volety, A.K., Winstead, J.T., Fisher, W.S., 1999. Influence of seasonal factors on oyster hemocyte killing of Vibrio parahemolyticus. National Shellfisheries Association. 


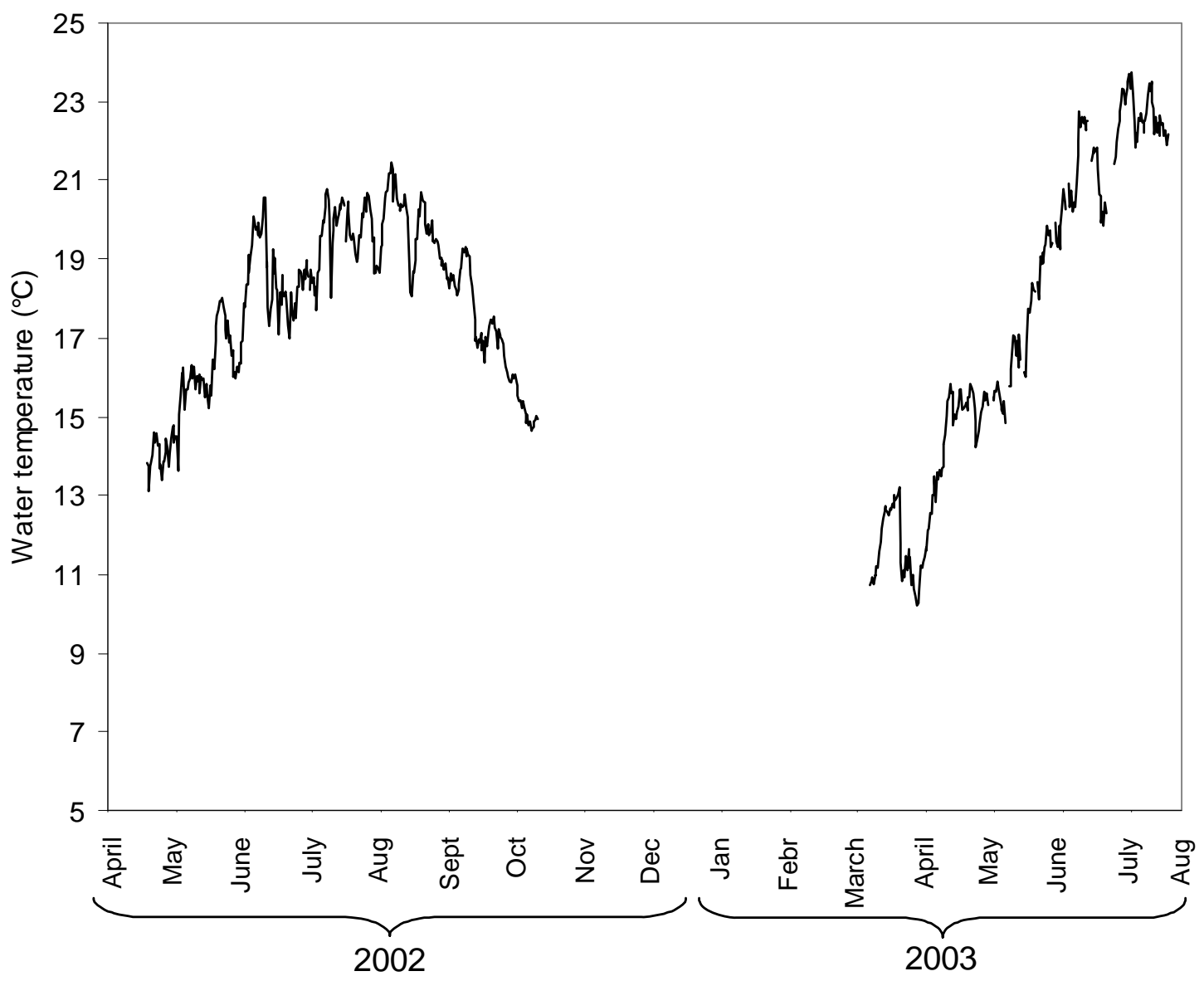

Figure 1: trend of water temperature during the course of experiments in 2002 and 2003. 
(a)

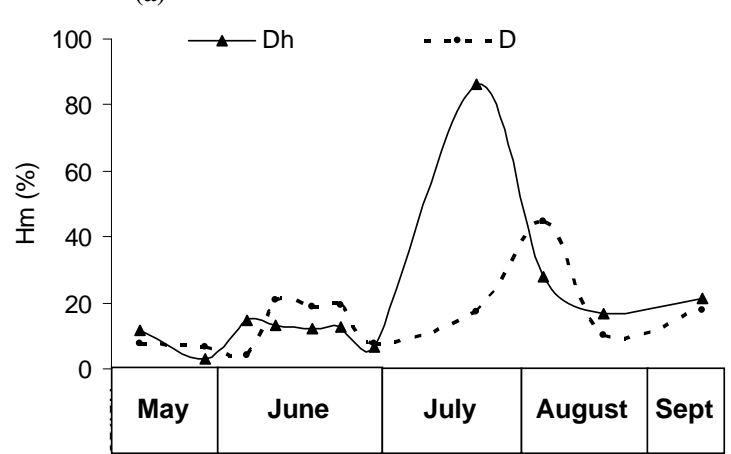

(c)

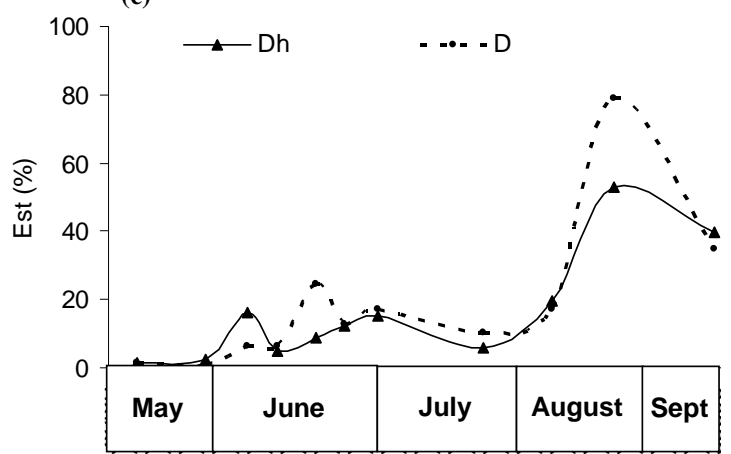

(e)

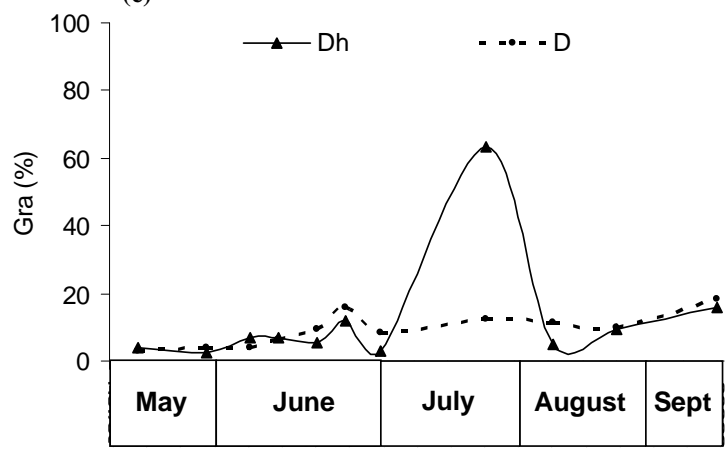

(b)

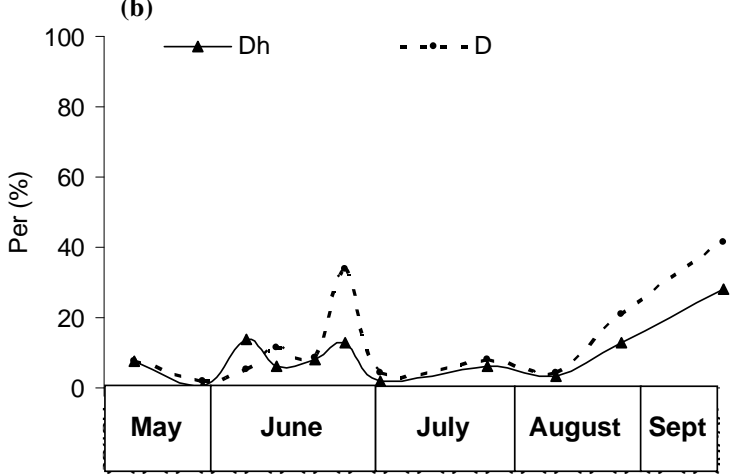

(d)

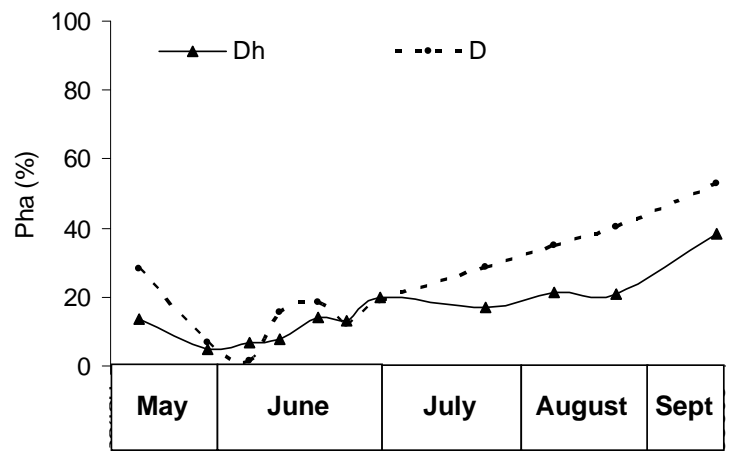

Figure 2. Percentage of dead cells (a), percentage of cells presenting a peroxidase activity (b), percentage of cells presenting an esterase activity (c), percentage of cells showing phagocytic activity (d) and granulocyte percentage (e) for diploids from natural beds (D) and hatchery diploids (Dh) during the 2002 experiment (May to September). 
(a)

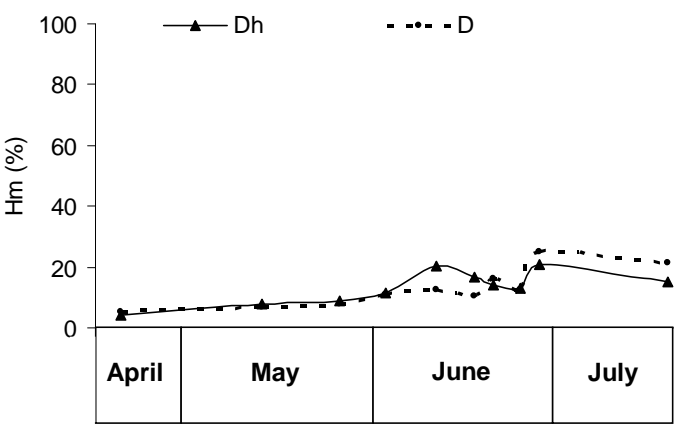

(c)

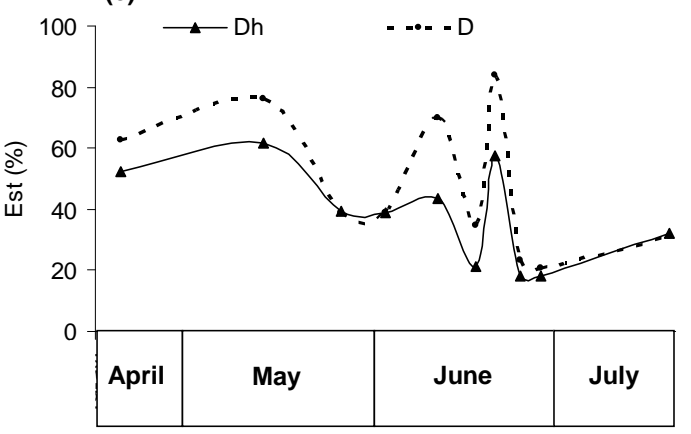

(e)

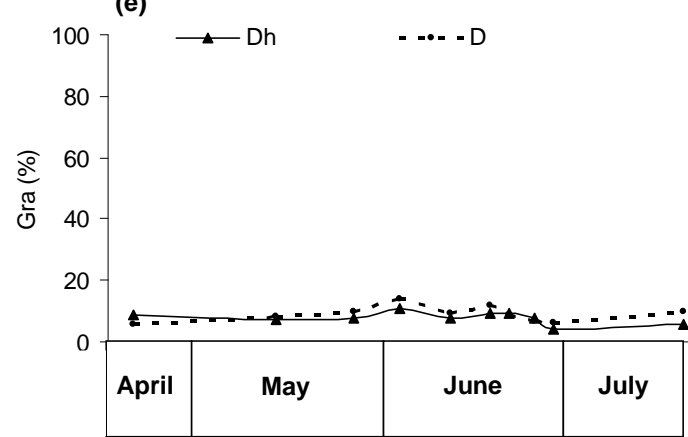

(b)

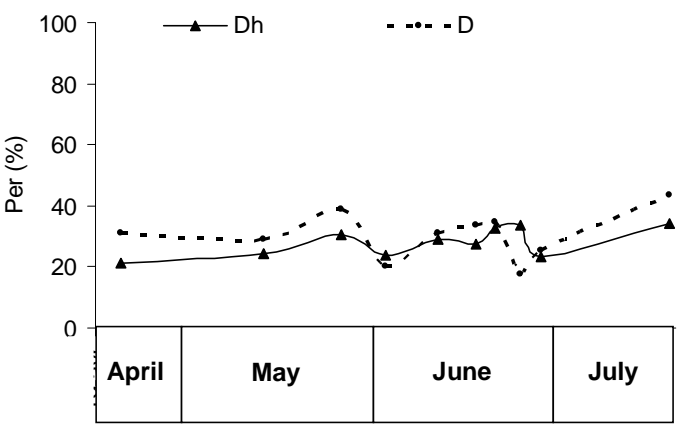

(d)

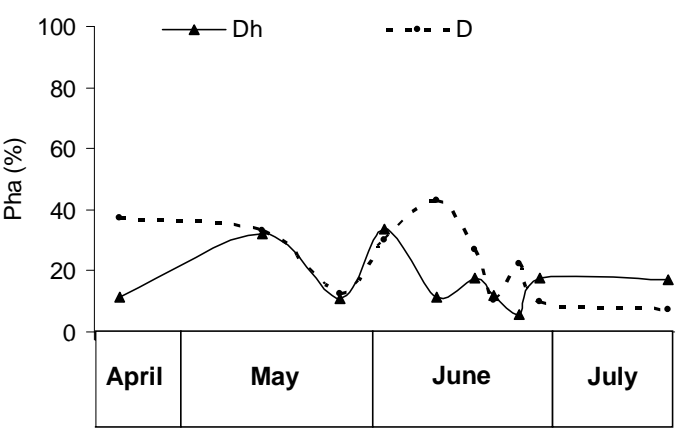

Figure 3. Percentage of dead cells (a), percentage of cells presenting a peroxidase activity (b), percentage of cells presenting an esterase activity (c), percentage of cells showing phagocytic activity (d) and granulocyte percentage (e) for diploids from natural beds (D) and hatchery diploids (Dh) during the 2003 experiment (April to July). 